\title{
DOSE-DEPENDENT EFFECT OF TRIBULUS TERRESTRIS DRY EXTRACT ON REPRODUCTIVE ORGANS OF GROWING MALE RABBITS
}

\author{
Desislava Abadjieva $^{1 *}$, Svetlana Grigorova ${ }^{2}$, Natasha Gjorgovska ${ }^{3}$, Elena Kistanova ${ }^{1}$ \\ ${ }^{11}$ Institute of Biology and Immunology of Reproduction, BAS, 73 Tzarigradsko shose, 1113 Sofia, Bulgaria \\ ${ }^{2}$ Institute of Animal Science, AA, sp. Pochivka, 2232 Kostinbrod, Bulgaria \\ ${ }^{3}$ Institute of Animal Science, "Ss. Cyril and Methodius" University in Skopje, \\ Blvd. Ilinden 92A, 1000 Skopje, North Macedonia \\ dessi_1@abv.bg
}

\begin{abstract}
A b s t r a c t: The aim of the study was to determine the effect of different doses of the Bulgarian product VemoHerb-T (dry extract of Tribulus terrestris L.) on the development of reproductive organs in growing male rabbits. In the experiment 35 male rabbits (White New Zealand breed) between 40 and 82 days of age were randomly divided into five groups - a control and four experimental groups. Different doses of VemoHerb-T (2.5, 5, $7.5 \mathrm{and} 10 \mathrm{mg} / \mathrm{kg}$ body weight for II, III, IV and V group, respectively) were added to the drinking water for the experimental groups. It was found that $T r$. terrestris affects the body and testicular weight of male growing rabbits in dose-dependent manner. The dose $2.5 \mathrm{mg} / \mathrm{kg}$ of the tested product can be recommended for use in rabbit breeding as the most appropriate and harmless. The higher doses of the extract induced negative histological changes in the rabbits' reproductive organs.
\end{abstract}

Key words: rabbits; testes; Tribulus terrestris extract

\section{ЕФЕКТ НА СУВ ЕКСТРАКТ ОД TRIBULUS TERRESTRIS ВРЗ РЕПРОДУКТИВНИТЕ ОРГАНИ НА МАШКИ ЗАЈАЦИ ВО РАЗВОЈ ВО ЗАВИСНОСТ ОД ДОЗАТА}

\begin{abstract}
А п с т р а к т: Целта на студијата беше да се определи ефектот на различни дози на бугарскиот производ VemoHerb-T (сув екстракт од Tribulus terrestris L.) врз развојот на репродуктивните органи кај машки зајаци во развој. Во експериментот 35 машки зајаци (сорта White New Zealand) на возраст од 40 до 82 дена беа поделени во пет групи по случаен избор - една контролна и четири експериментални. Во водата за пиење за експерименталните групи беа додадени различни дози на VemoHerb-T (2,5; 5; 7,5 и $10 \mathrm{mg} / \mathrm{kg}$ телесна тежина, за II, III, IV и V група, соодветно). Беше утврдено дека Tr. terrestris влијае врз телесната и врз тестикуларната тежина на машките зајаци во развој во зависност од употребената доза. Дозата на тестираниот продукт од 2,5 $\mathrm{mg} / \mathrm{kg}$ може да се препорача за употреба во одгледувањето зајаци како најсоодветна и нештетна. Повисоките дози на екстрактот индуцираа негативни хистолошки промени кај репродуктивните органи на зајаците.
\end{abstract}

Клучни зборови: зајаци; тестиси; екстракт од Tribulus terrestris

\section{INTRODUCTION}

A lot of herbs and their extracts have been used in the traditional medicine of different countries. Today, about $80 \%$ of the world's population prefers to apply herbal treatment for maintaining the health or for treatment of diseases. Even the World Health Organization recommends the inclusion of herbal medicaments in national health programs, because they are readily available and harmless (Chaudhury, 1999). In the recent years there is an ever-growing use of herbal extracts in the animal husbandry, as natural dietary additives as well as an alternative to the antibiotics and synthetic hormones administered with the feed (Javed et al., 2012). Biologically active substances of medical plants have a positive influence on the health status, and the productive and reproductive performances of animals. The 
prostrate annual herb Tribulus terrestris L. (Zygophyllaceae) contains biologically active substances such as furostanol saponins (protodioscin and protogracylin - the main active components of this plant), flavonoids, alkaloids, vitamins, polyunsaturated fatty acids, tannins, etc. (Dinchev et al., 2010). The extract from Tribulus terrestris has a broad spectrum of actions: hypoglycemic, anti-microbial, anti-inflammatory and anti-cancer (Sisto et al., 2012; Gandhi et al., 2013; Hammoda et al., 2013). On the base of experiments with laboratory animals it was concluded that Tribulus terrestris effect on male animals' reproductive system is achieved by activation of luteinizing hormone (LH), which in turn stimulates testosterone secretion (Tomova et al., 1981). However, there are very limited data about Tribulus terrestris effect on rabbits' reproductive system.

The aim of this study, which is new in this field, was to determine the effect of different doses of the Bulgarian product VemoHerb-T (dry extract of Tribulus terrestris L.) on the development of reproductive organs in growing male rabbits.

\section{MATERIALS AND METHODS}

An experiment was conducted at the Experimental Base of the Institute of Animal Science Kostinbrod, Bulgaria, with a total of 35 male growing rabbits (White New Zealand breed) at the age of 40 days and $1 \mathrm{~kg}$ initial average body weight, in accordance with the Bulgarian Veterinary Law. The rabbits were randomly divided in five groups: a control (I group) and four experimental groups (II, III, IV, V). The animals were housed in single cages. All the groups were fed ad libitum with the same granulated Total Mixed Ration (TMR) for growing rabbits, with the following chemical composition: crude protein $-18.31 \%$; crude fiber $-16.31 \%$; lysine $-0.87 \%$; methionine + cystine $-0.77 \%, \mathrm{Ca}-$ $1.16 \%, \mathrm{P}-0.62 \%, \mathrm{ME}-2,250 \mathrm{kcal} / \mathrm{kg}$. The experimental groups were receiving different doses of the tested product VemoHerb-T (commercial name of the Bulgarian Tribulus terrestris L. extract, produced by Vemo-99 Company Ltd., Sofia, Bulgaria): $2.5 \mathrm{mg}, 5 \mathrm{mg}, 7.5 \mathrm{mg}, 10 \mathrm{mg} / \mathrm{kg}$ body weight, during 42 days (Table 1). VemoHerb-T was added to the morning drinking water.

The body weight was controlled every 7 days; the general health status of the rabbits every day. At the end of the experiment the rabbits were humanely killed in accordance with the Directive 2010/63/EC of the European Parliament (http://w ww.europ
arl.europa.eu/sides/getDoc.do?pubRef=-//EP//TE $\mathrm{XT}+\mathrm{REPORT}+\mathrm{A} 7-2012-0216+0+\mathrm{DOC}+\mathrm{XTML}+\mathrm{V}$ $0 / / \mathrm{BG})$.

Table 1

Experimental scheme

\begin{tabular}{lccccc}
\hline \hline & \multicolumn{5}{c}{ Groups } \\
Parameters & I & II & III & IV & V \\
\hline $\begin{array}{l}\text { Number of rabbits } \\
\begin{array}{l}\text { VemoHerb-T, } \\
\text { mg/kg body weight }\end{array}\end{array}$ & 7 & 7 & 7 & 7 & 7 \\
\hline \hline
\end{tabular}

The testes and epididymis were separated carefully, cleaned of fat, weighed and fixed in $10 \%$ formalin for 24 to 48 hours. The tissues were dehydrated in ascending alcohol series and inserted in paraffin blocks. Serial sections with a thickness of 5 $\mu \mathrm{m}$ were cut using a hand microtome, mounted on slides and stained with hematoxylin-eosin by a routine method. The samples were prepared and analyzed using a microscope Olympus BX51 (Tokyo, Japan), in the laboratory of IBIR - BAS.

The results obtained were statistically processed by a computer program Excel 2007. The values are presented as mean \pm statistical error for each variable. Differences were estimated by t-test of Student and considered significant within $\mathrm{P} \leq 0.05$.

\section{RESULTS AND DISCUSSION}

In Table 2 are shown the values of body weight at the end of the experiment and the weight of the testes in male growing rabbits from all the groups. The rabbits from all experimental groups had a statistically higher body weight in comparison with the control group $(\mathrm{P}<0.001)$. The results obtained are in accordance with other authors, who established a significant increase of body weight in rats treated with different doses of Tribulus terrestris (Gauthaman et al., 2003). This effect can be explained by the androgenic effect of the tested product, which probably stimulates the appetite. Androgens play an important role in the growth and development of reproductive tissue and in the differentiation of other tissues. Rabbits' ejaculate contains about $24 \times 10^{6}$ sperm produced by $1 \mathrm{~g}$ of testis (Hafez, 1970). However, this parameter can be affected by changes in the weight of sexual organs, body weight, sexual 
activity, hormonal imbalance, etc. Also, testicular weight reflects the variation of the androgen status. The lower value of this index is most likely due to a decrease of serum testosterone (Simanainen et al., 2008). In our research, the tested product influenced the testis weight. In the rabbits receiving $2.50 \mathrm{mg}$ of VemoHerb$\mathrm{T} / \mathrm{kg}$ body weight, the values of this parameter were significantly higher in comparison with the control group $(\mathrm{P}<0.01)$ and the other experimental groups $(\mathrm{P}<0.01 ; \mathrm{P}<0.05 ; \mathrm{P}<0.01$ for III, IV and V experimental groups, respectively). With increasing the dose of VemoHerb$\mathrm{T}$, the testicular weight varied. A magnification was observed in the groups treated with 5.00 $\mathrm{mg} / \mathrm{kg}$ body weight $(\mathrm{P}<0.01)$ or $7.50 \mathrm{mg} / \mathrm{kg}$ body weight $(\mathrm{P}<0.05)$, compared to the control group. There was no increase of the testis weight in the rabbits receiving $10 \mathrm{mg}$ of VemoHerb-T/kg body weight. Probably the higher dose of protodioscin has a suppressive effect on the secretion of LH. This leads to a reduced testosterone secretion from Leydig cells (Arsyad, 1997).

Table 2

Body weight and testicular weight of rabbits from control and experimental groups

\begin{tabular}{lll}
\hline \hline Groups & Body weight $(\mathrm{g})$ & $\begin{array}{l}\text { Mean weight of } \\
\text { paired testes }(\mathrm{g})\end{array}$ \\
\hline I (0) - control group & $2543 \pm 1.91 \mathrm{a}, \mathrm{b}, \mathrm{c}, \mathrm{d}$ & $2.33 \pm 0.02 \mathrm{e}, \mathrm{f}, \mathrm{g}$ \\
II $(2.50)$ & $2707 \pm 1.74 \mathrm{a}$ & $3.44 \pm 0.31 \mathrm{e}$ \\
III (5.00) & $2667 \pm 5.43 \mathrm{~b}$ & $3.36 \pm 0.30 \mathrm{f}$ \\
IV (7.50) & $2604 \pm 3.64 \mathrm{c}$ & $2.63 \pm 0.13 \mathrm{~g}$ \\
V (10.00) & $2656 \pm 8.17 \mathrm{~d}$ & $2.34 \pm 0.07$ \\
\hline \hline
\end{tabular}

Significance: $\mathrm{g}=\mathrm{P}<0.05 ; \mathrm{e}, \mathrm{f}=\mathrm{P}<0.01 ; \mathrm{a}, \mathrm{b}, \mathrm{c}, \mathrm{d}=\mathrm{P}<0.001$

VemoHerb-T dose of $2.50 \mathrm{mg} / \mathrm{kg}$ body weight positively influenced the development of gonadal tissue (Figure 1C). The population of cells in the lumen of the seminiferous tubules was higher in comparison with the control group. Similarly, sperm cells were noticed in the lumen of the seminiferous tubules of the rabbits receiving VemoHerb- $\mathrm{T}$ in the dose of $5.00 \mathrm{mg} / \mathrm{kg}$ body weight (Figure 1B). However, in this group changes in the epithelial layer of gonads and a loss of Leydig cells were found. This may have a future negative effect on sperm quality, because it is known about the important role of the epithelium in the production of luminal fluid (Syed and Hecht, 2002). At an optical microscopy level no atrophic changes were noticed, but a loss of normal intracytoplasmatic contacts was found. That should explain the loss of Leydig cells in these testicular tissues.

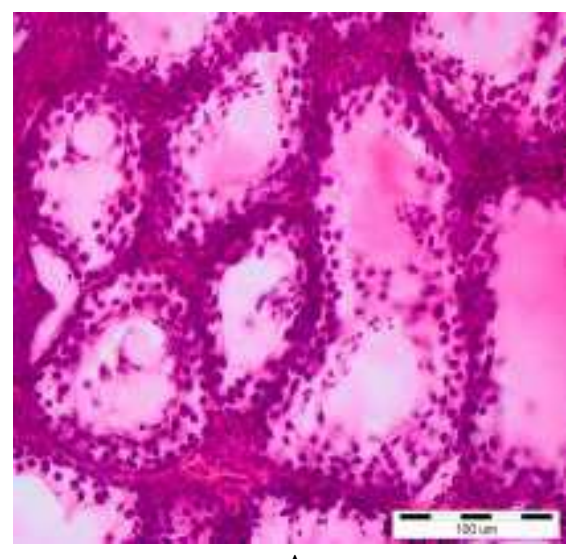

A

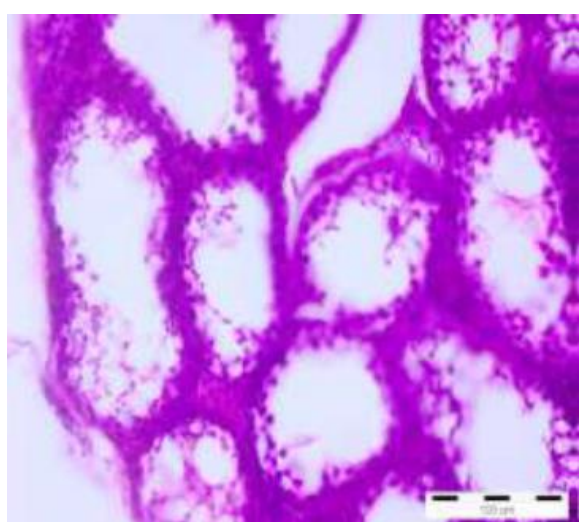

B

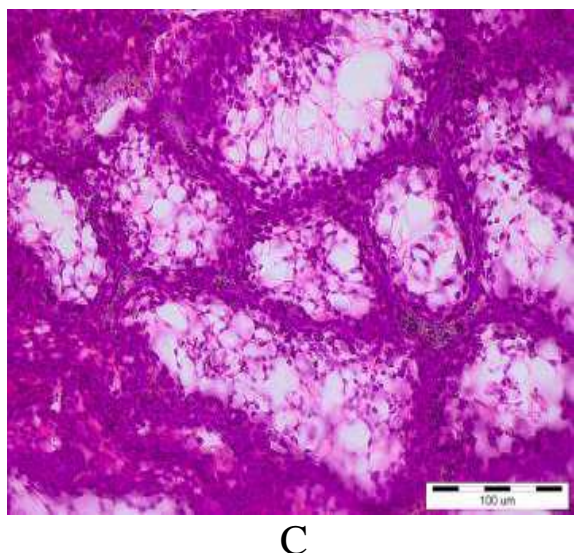

Fig. 1. Photomicrographs of H\&E stained rabbit testis sections showing the effect of Tribulus terrestris: A) control group $(\times 40)$, B) III exp. group $(\times 40), C)$ I exp. group $(\times 40)$ 
The overdose of steroid saponins from the additive, probably, inhibits the proliferation of Leydig cells and the production of testosterone, which negatively affects the spermatocytes' differentiation (Saez, 1994). Similar results were obtained in male wistar rats in the experiment performed by Saalu et al. (2013), who used high doses $(300 \mathrm{mg} / \mathrm{kg}$ and $600 \mathrm{mg} / \mathrm{kg} /$ day $)$ of Vernonia amygdalyna herb extract, administered by oral route. They underline that the toxic effect of this herb on the testes manifested in the reduced density of seminiferous tubules and in the reduction of tubular diameter and lack of sperm in the lumens. Our investigation showed that the higher doses of VemoHerb-T $(7.50 \mathrm{mg} / \mathrm{kg}$ and 10 $\mathrm{mg} / \mathrm{kg}$ body weight) provoked hypertrophia in the epididymis (Figure 2). According to Mcgavin and Zachary (2007), probably a reaction of the reproductive tissues sensitive to the extract of Tribulus terrestris led to the cell proliferation. Moreover, in these groups an adipose tissue accumulation in the epididymis was noticed (Figure 2B). Having in mind all the aforesaid, it is very important to determine the correct dose of the product VemoHerb-T as feed additive in the livestock diet.
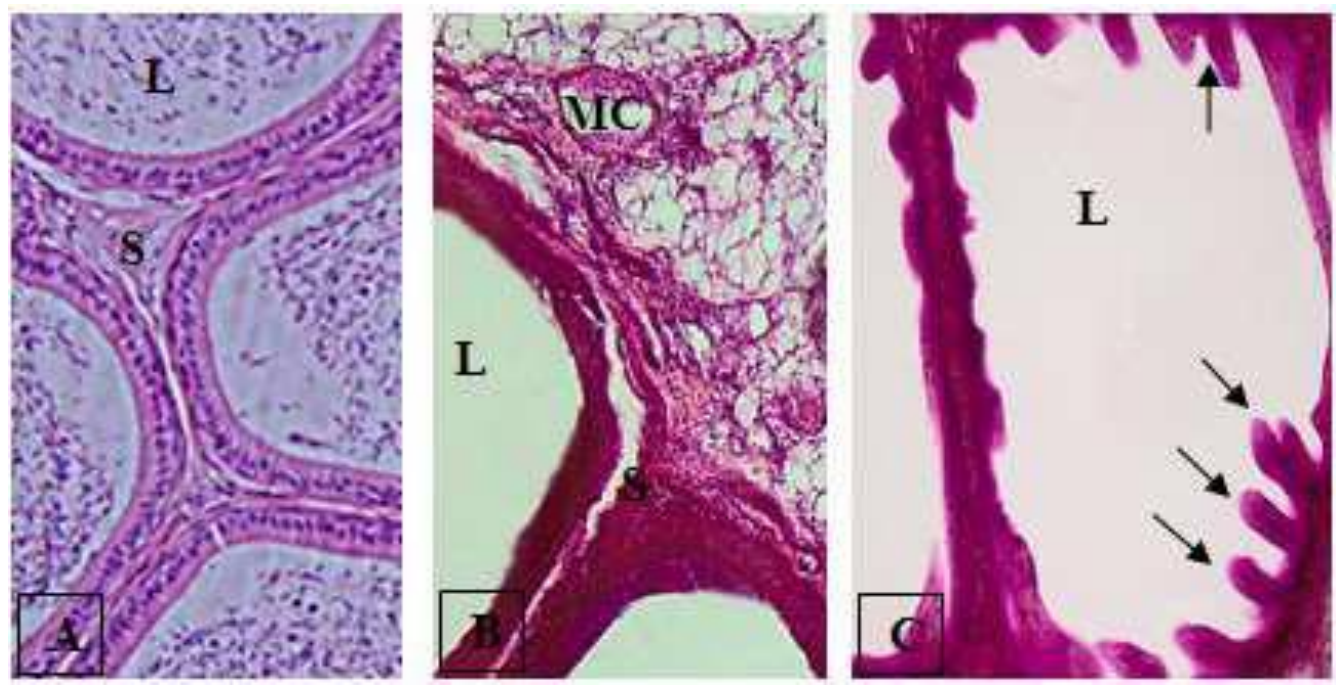

Fig. 2. Photomicrographs of H\&E stained rabbit epididymis sections showing the effect of Tribulus terrestris $(\times 20)$ : A) control group, B) IV exp. group, C) V exp. group; $\mathrm{L}=$ lumen, $\mathrm{S}=$ stroma, $\mathrm{MC}=$ fast cells, arrows = epithelial infolding.

\section{CONCLUSION}

The tested product VemoHerb-T (Tribulus terrestris extract) affected rabbits' body weight and testicular weight. This effect depends on the dose. The lower dose $(2.50 \mathrm{mg} / \mathrm{kg}$ body weight $)$ used in this investigation can be recommended as the most effective and harmless, because it ensures maximal body weight gain as well as normal development of the histological structures in the testes and epididymis. The higher doses of the tested product provoked abnormal morphological changes in the testes and epididymis that can affect the spermatogenesis and lead to a decrease of sperm quality in mature rabbits.

Acknowledgments: This research was supported by the project № DKOST01/10 - Ministry of Education and Science of Bulgaria and COST Action FA1403. We also thank the producer Company "VEMO-99", Sofia, Bulgaria, for providing the feed additive VemoHerb-T.

\section{REFFERENCES}

[1] Arsyad, K. M.: Effect of protodioscin (Tribulus terrestris) on the well-being and sexual response of men with diabetes mellitus. International Journal of Impotence Research, vol. 8, pp. 23-29 (1997).

[2] Chaudhury, R. R.: Herbal Medicine for Human Health. World Health Organization, Geneva, CBS Publishers and Distributors LTD: New Delhi, 1999.

[3] Dinchev, D., Evstatieva, L., Platikanov, S., Galambosim, B.: Investigation of perspective origins of Tribulus terrestris L. for cultivation. Comptes rendus de l'Academie Bulgare des Sciences, vol. 63, pp. 1429-1434 (2010).

[4] Gandhi, S., Srinivasan, B. P., Akarte, A. S.: Potential nephrotoxic effects produced by steroidal saponins from hydro alcoholic extract of Tribulus terrestris in STZinduced diabetic rats. Toxicology Mechanism and Methods, vol. 23, pp. 548-557 (2013).

[5] Gauthaman, K., Ganesan, A. P., Prasad, R. N.: Sexual effects of puncture vine (Tribulus terrestris) extract (protodioscin): An evaluation using a rat model. Journal of 
Alternative and Complementary Medicine, vol. 9, pp. 257265 (2003).

[6] Hafez, E. S. E.: Reproduction and Breeding Techniques for Laboratory Animals. Lea and Febiger, Philadelphia, 1970.

[7] Hammoda, H. M., Ghazy, N. M., Harraz, F. M., Radwan, M. M., ElSohly, M. A., Abdallah, I. I.: Chemical constituents from Tribulus terrestris and screening of their antioxidant activity. Phytochemistry, vol. 92, pp. 153-159 (2013).

[8] Javed, Y., Khan, S., Chand, N., Mushtaq, M.,, Sultan, A., Rafiullah, A., Tanweer, A. J.: Comparative efficacy of different schedules of administration of medicinal plants mixed infusion of hematology of broiler chicks. Sarhad Journal of Agriculture, vol. 28, pp. 327-331 (2012).

[9] Mcgavin, M. D., Zachary J. F.: Pathologic Basis of Veterinary Disease. 4th ed. Mosby Elsevier, St. Louis, Missouri (2007).

[10] Saalu, L. C., Akunna, G. G., Oyewopo, A. O.: The histomorphometric evidences of Vernonia amygdalina, leaf extract - induced testicular toxicity. International Journal of Morphology, vol. 31, pp. 662-667 (2013).

[11] Saez, J. M.: Leydig cells: endocrine, paracrine and autocrine regulation. Endocrine Reviews, vol. 15, pp. 574-626 (1994).
[12] Simanainen, U., Mcnamara, K., Davey, R. A., Zajac J. D., Handelsman, D.: Severe subfertility in mice with androgen receptor inactivation in sex accessory organs but not in testis. Endocrinology, vol. 8, pp. 49-330 (2008).

[13] Sisto, M., Lisi, S., D'amore, M., De Lucro, R., Carati, D., Castellana, D., Lapesa, V., Zuccarello, D., Lofrumento, D. V.: Saponins from Tribulus terrestris L. protect human keratinocytes from UVB-induced damage. Journal of Photochemistry and Photobiology, vol. 117, pp. 193-201 (2012).

[14] Syed, V., Hecht, N. B.: Disruption of germ cell -Sertoli cell interactions leads to spermatogenic defects. Molecular and Cellular Endocrinology, vol. 186, pp. 155-157 (2002).

[15] Tomova, M., Gyulemetova, R., Zarkova, S., Peeva, S., Pangarova, T., Simova, M.: Steroidal saponins from Tribulus terrestris L. with a stimulating action on the sexual functions. Proceedings of the First International Conference of Chemistry and Biotechnology of Biologically Active Natural Products, pp. 289-291 (1981).

[16] http://www.europarl.europa.eu/sides/getDoc.do?pubRef=//EP//TEXT+REPORT+A7-2012-0216+0+DOC+XML+ $\mathrm{V} 0 / / \mathrm{BG}$ 
